\title{
Evaluating the Anxiety Levels of Parents of Children Underwenting Hypospadias Surgery
}

\author{
Hipospadias Cerrahisi Geçiren Çocukların Ebeveynlerinin Kaygı Düzeyinin Değerlendirilmesi
}

\author{
Ali Onur ERDEM ${ }^{1}$ \\ (D) 0000-0002-9584-4200 \\ Bilge DOĞAN ${ }^{2}$ \\ (1) 0000-0001-7895-9738 \\ Çağdaş Öykü MEMIŞ̧ ${ }^{2}$ \\ (i) 0000-0001-6777-4172 \\ Levent SEVINÇOK ${ }^{2}$ \\ (1) 0000-0003-3770-8881 \\ Mesut YAZICI ${ }^{1}$ \\ (D) 0000-0003-1960-7825 \\ Sezen ÖZKISACIK ${ }^{1}$ \\ (D) 0000-0003-3302-727X
}

\begin{abstract}
${ }^{1}$ Adnan Menderes University Faculty of Medicine Department of Pediatric Surgery, Aydın, Turkey

${ }^{2}$ Adnan Menderes University Faculty of Medicine Department of Psychiatry, Aydın, Turkey
\end{abstract}

\section{Corresponding Author Sorumlu Yazar \\ Ali Onur ERDEM \\ aoerdem@adu.edu.tr}

Received / Geliş Tarihi : 27.11.2019 Accepted / Kabul Tarihi : 18.03.2020 Available Online /

Çevrimiçi Yayın Tarihi : 25.04.2020

\begin{abstract}
Aim: Hypospadias is an anomaly in which urethral meatus is located more proximally. Its treatment is surgery. Children undergoing hypospadias surgery are much more prone to emotional disorders than the other surgical procedures. In this study, it was aimed to evaluate the emotional and temperament characteristics of the parents of children undergoing hypospadias surgery and normally circumcised.

Material and Methods: All voluntary parents of children with hypospadias surgery and of children with normal circumcision were included in this study. A semi-structured sociodemographic data form, The Temperament Evaluation of Memphis, Pisa, Paris and San Diego Autoquestionnaire (TEMPS-A), State-Trait Anxiety Inventory (STAI) I-II, and Beck Depression Scale (BDS) were used to collect data from these parents.

Results: There was no significant difference between the parents in terms of sociodemographic and clinical characteristics. When the parents of children with hypospadias and normal circumcision were compared in terms of TEMPS-A temperament scale scores, STAI total and I-II subscale scores, and BDS scores, no statistically significant difference was found.

Conclusion: Hypospadias is a complex biological development defect. In men who underwent hypospadias surgery, sexual dysfunctions that develop in further period usually develop on psychological grounds. Parents' anxiety levels should be taken into consideration and everyone should act together in management process of hypospadias, operation of which is planned in early period and may have many effects in the future. We think that the study we have done with parents in this area may guide to other studies.

Keywords: Anxiety; parents; hypospadias; children; surgery.
\end{abstract}

\section{ÖZ}

Amaç: Hipospadias, üretral meanın daha proksimalde lokalize olduğu bir anomalidir. Cerrahi olarak tedavi edilir. Hipospadias cerrahisi geçiren çocuklar, duygusal bozukluklara diğer cerrahi yöntemlere göre daha fazla yatkın olmaktadırlar. Bu çalışmada normal sünnet yapılan ve hipospadias cerrahisi geçiren çocukların ebeveynlerinin duygusal ve karakteristik mizaçlarının değerlendirilmesi amaçlanmıştır.

Gereç ve Yöntemler: Bu çalışmaya hipospadias cerrahisi geçiren çocukların ve normal sünnet yapılan çocukların ebeveynlerinden gönüllü olanların tümü dahil edilmiştir. Ebeveynlerden veri toplamak için yarı yapılandırılmış sosyodemografik veri formu, Memphis, Pisa, Paris ve San Diego Mizaç Değerlendirme Anketi (The Temperament Evaluation of Memphis, Pisa, Paris and San Diego Autoquestionnaire, TEMPS-A), Durumluluk-Süreklilik Kaygı Envanteri (State-Trait Anxiety Inventory, STAI) I-II ve Beck Depresyon Ölçeği (BDÖ) kullanılmıştır. Bulgular: Ebeveynler arasında klinik ve sosyodemografik özellikler açısından anlamlı bir fark yoktu. Hipospadiaslı olan ve normal sünnet olan çocukların ebeveynleri TEMPS-A mizaç ölçeği puanları, STAI toplam ve I-II alt ölçek puanları ve BDÖ puanları açısından karşıllaştırıldığında da istatistiksel olarak anlamlı bir fark bulunmadı.

Sonuç: Hipospadias karmaşık bir biyolojik gelişme defektidir. Hipospadias ameliyatı geçiren erkeklerde, ileriki dönemde gelişen cinsel işlev bozuklukları genellikle psikolojik nedenlerle gelişir. Ebeveynlerin kaygı düzeyleri dikkate alınmalı ve operasyonu erken dönemde planlanan ve gelecekte birçok etkisi olabilecek olan hipospadias tedavi sürecinde herkes birlikte hareket etmelidir. Bu alanda ebeveynlerle yaptığımız bu çalışmanın diğer çalışmalara rehberlik edebileceğini düşünüyoruz.

Anahtar kelimeler: Kaygı; ebeveynler; hipospadias; çocuk; cerrahi. 


\section{INTRODUCTION}

Hypospadias is an anomaly in which urethral meatus is located more proximally on the anterior aspect of the penis. The cause of this anomaly seen in one of 300 boys is unknown and its treatment is surgery (1). Surgical management of hypospadias is generally completed in childhood. It is thought that in patients with hypospadias, psychological, psychosexual and psychosocial problems may be seen not only during treatment but also in adolescence and adulthood. While preliminary studies support this thought, most of the controlled studies conducted in recent years indicate that hypospadias cases do not differ from their controls. There are inconsistencies in the results of the research due to the fact that patients are being less traumatized as a result of changes in surgical technique and applications and treatment can be completed at much earlier ages (before 30 months) compared to the past (2-5).

Children undergoing hypospadias surgery are much more prone to emotional disorders than the average population (6-8). There are some studies about children and their emotional disorders in the literature, but there is no study about emotional disorders of parents with children undergoing hypospadias surgery. In this study, we aimed to present the emotional and temperament characteristics of the parents in the evaluation of this disorder in children by comparing the parents of children undergoing hypospadias surgery and of children who are normally circumcised, in terms of some sociodemographic and clinical variables, anxiety levels and affective temperament characteristics.

\section{MATERIAL AND METHODS}

Approval of Adnan Menderes University Ethics Committee was obtained (approval no: 2018/1413 and approval time: 07.06.2018). The aims and the all procedures of the study were explained to both parents of the hypospadias and circumcision groups by a trained psychiatrist.

\section{Participants}

Forty six parents of children with hypospadias and 50 parents of children with normal circumcision (aged 18 and older, with written consent, and those without any communication and comprehension difficulties that may prevent the administration of the study scales) who admitted to Department of Pediatric Surgery of Adnan Menderes University between June 2018 and June 2019 were included to in the study.

\section{Data Collection Tools}

A semi-structured sociodemographic data form, The Temperament Evaluation of Memphis, Pisa, Paris and San Diego Autoquestionnaire-(TEMPS-A) temperament scale, State-Trait Anxiety Inventory(STAI) I-II and Beck Depression Scale (BDS) were used during the interview with 46 parents of children with hypospadias and 50 parents of children with normal circumcision.

Sociodemographic Data Form for Family and Child: In this form, parents of children with hypospadias and of children with normal circumcision were questioned in terms of their child's future sexual life and sexual orientation, besides sociodemographic characteristics about child and his family. The form was filled in by parents.
State-Trait Anxiety Inventory (STAI) I-II: According to Two-Factor Anxiety Theory, Spielberger et al. (9) divided anxiety into two as State and Trait Anxiety. State Anxiety is the anxiety that occurs when a dangerous, undesirable situation is encountered. Trait Anxiety is an anxiety that exists when there is no objective reason, and when there is, it is disproportionately long-term and violent with this situation (10). Every person feels anxiety when he/she thinks it is dangerous. Fear and anxiety caused by dangerous conditions are considered as temporary and normal anxiety experienced by the individual. It is called State Anxiety. When the stress is intense, the state anxiety level increases, and when the stress disappears, it falls. Some consistently live in uneasiness and are often unhappy. This type of anxiety, which does not depend on the dangers directly from the environment, is endogenous. Individuals feel anxiety if they think that their core values are threatened or if they interpret the situations they are in as stressful. It is called Trait Anxiety. Continuous anxiety is steady and it is generally stated that it is a personal trait (11).

The Temperament Evaluation Scale (The Temperament Evaluation of Memphis, Pisa, Paris and San-Diego Autoquestionnaire, TEMPS-A): It was developed by Akiskal et al. (12) to evaluate the dominant affective temperament. The questionnaire consists of 100 questions designed to determine depressive, hyperthymic, irritable, cyclothymic and anxious temperaments. The person responds to the questions as yes or no, considering his or her whole life. To determine the presence of dominant depressive (19 questions), cyclothymic (19 questions), hyperthymic (20 questions), irritable (18 questions) and anxious (24 questions) temperament characteristics in an individual, cut points are 13,18, 20, 13 and 18 points respectively. The validity and reliability studies of the Turkish version were performed by Vahip et al. (11). Test-retest reliability of the Turkish form calculated separately for each temperament trait is between 0.73-0.93, and the Cronbach-alpha coefficient is between 0.77-0.85. TEMPS-A was applied to patients aged 16 years and older and to their mothers.

Beck Depression Scale (BDS): Scale developed by Beck et al. (13) and is used to determine the risk for depression and to measure the level and intensity change of depression symptoms. It includes 21 self-evaluation sentences. Point interval ranges from 0 to 63 . Validity and reliability of the Turkish form was made by Hisli N. (14).

\section{Statistical Analysis}

Data obtained from the study were analyzed with SPSS 20 statistical package. The normal distribution of the numerical data was examined using Shapiro-Wilk test, and homogeneity of variances using Levene test. Independent samples t or Mann-Whitney U test was used to compare two groups according to normality assumption. Categorical data were analyzed with Pearson chi-square or Fisher's exact test, as appropriate. Two-way analysis of variance was used to investigate both main and interaction effects of group and gender. Descriptive statistics were summarized as mean \pm standard deviation or median (minimum maximum), and frequency and percentage, as appropriate. A p value equal to or below 0.05 level was considered as statistically significant. 


\section{RESULTS}

A total of 96 parents with a mean age of 35.6 \pm 7.0 (range, 21 to 57) years, 46 of whose child were underwent hypospadias and 50 were underwent normal circumcision were included in the study. There was no significant difference between the parents of normal circumcision and hypospadias groups in terms of age, gender, marital status, employment status, and region of residence (Table 1).

There were $1(3.8 \%)$ parent with a psychiatric diagnose in normal circumcision group and $2(4.5 \%)$ parents in hypospadias group, and no significant difference was found between the groups $(\mathrm{p}=0.606)$. Information of parents about hypospadias was higher in hypospadias $(\mathrm{n}=37,80.4 \%)$ group compared to normal circumcision $(n=29,58.0 \%)$ group $(\mathrm{p}=0.018)$. Concern of parents about child's homosexuality were not significantly different between the groups in general $(p=0.227)$. Although there was no statistically significant difference between groups, two parents (one mother and one father) in the hypospadias group were concerned about child's homosexuality, while none of the parents in the normal circumcision group. Additionally, concern about child's sexuality was found lower in hypospadias $(\mathrm{n}=12,26.1 \%)$ group compared to normal circumcision $(\mathrm{n}=23,46.0 \%)$ group $(\mathrm{p}=0.043)$. When concerns of parents examined separately, as mothers and fathers, it was observed that similar results were obtained for comparison of groups. On the other hand, when mothers and fathers are compared each other in each group, it was seen that there was no significant difference, that is, being a mother or father does not affect these concerns (Table 2).

We have also found no differences in affective temperament and BDI scales. There were no significant differences between the mothers and fathers of the children with hypospadias and normal circumcision groups with regard to depression, anxiety scores, and affective temperaments.

When the effect of normal circumcision and hypospadias groups, and parent's gender effect evaluated together, there was no significant interaction in terms of STAI-I $(\mathrm{p}=0.379)$, STAI-II $(p=0.867)$ and total $(p=0.673)$ scale points. While there was no significant difference between normal circumcision and hypospadias groups $(\mathrm{p}=0.500, \mathrm{p}=0.291$ and $\mathrm{p}=0.811$, respectively), it was observed that being a mother or father in general was not statistically significantly affect the scale points $(\mathrm{p}=0.980, \mathrm{p}=0.071$ and $\mathrm{p}=0.278$, respectively). Parents of hypospadias group regardless of being a mother or father had lower scale points compared to normal circumcision group in terms of STAI-II and total scores, except STAI-I score. Fathers of children with hypospadias had highest STAI-I score, while mothers of them had the lowest, even lower than the parents of normal circumcision group (Table 3, Figure 1).

When the effect of information about hypospadias and parent's gender effect on STAI scale evaluated together, there was no significant interaction in terms of STAI-I $(\mathrm{p}=0.537)$, STAI-II $(\mathrm{p}=0.779)$ and total $(\mathrm{p}=0.588)$ scale points. While there was no significant difference between parents with and without information about hypospadias $(\mathrm{p}=0.514, \mathrm{p}=0.700$ and $\mathrm{p}=0.873$, respectively), it was observed that being a mother or father in general was not statistically significantly affect the scale points $(\mathrm{p}=0.201$, $p=0.587$ and $p=0.655$, respectively). Fathers of hypospadias group regardless of having information about hypospadias had higher scale points compared to mothers in terms of
STAI-I and total scores, except STAI-II score. Additionally, fathers of children not having information about hypospadias had highest STAI-I and total scores, while mothers of them had the lowest regardless of having or not any information about hypospadias (Table 4, Figure 2).

Table 1. Comparisons of parents in normal circumcision and hypospadias groups in terms of sociodemographic

\begin{tabular}{|c|c|c|c|}
\hline & $\begin{array}{c}\text { Normal } \\
\text { circumcision } \\
(\mathbf{n}=\mathbf{5 0})\end{array}$ & $\begin{array}{c}\text { Hypospadias } \\
(n=46)\end{array}$ & $\mathbf{p}$ \\
\hline \multicolumn{4}{|l|}{ Gender, n (\%) } \\
\hline Female & $24(48.0)$ & $24(52.2)$ & \multirow{2}{*}{0.683} \\
\hline Male & $26(52.0)$ & $22(47.8)$ & \\
\hline \multicolumn{4}{|l|}{ Marital status, n (\%) } \\
\hline Single & $0(0.0)$ & $0(0.0)$ & \multirow{3}{*}{0.118} \\
\hline Married & $46(92.0)$ & $46(100)$ & \\
\hline Divorced/widow & $4(8.0)$ & $0(0.0)$ & \\
\hline \multicolumn{4}{|l|}{ Employment, n (\%) } \\
\hline Employed & $29(58.0)$ & $27(58.7)$ & \multirow{2}{*}{0.945} \\
\hline Unemployed & $21(42.0)$ & $19(41.3)$ & \\
\hline \multicolumn{4}{|l|}{ Place of residence, $n(\%)$} \\
\hline Urban & $24(48.0)$ & $22(47.8)$ & \multirow{2}{*}{0.986} \\
\hline Rural & $26(52.0)$ & $24(52.2)$ & \\
\hline $\begin{array}{l}\text { Age of parent (years), } \\
\text { Mean } \pm \text { SD }\end{array}$ & $35.7 \pm 6.3$ & $35.6 \pm 7.7$ & 0.903 \\
\hline \multirow{2}{*}{$\begin{array}{l}\text { Age of child (months), } \\
\text { Median (IQR), min-max }\end{array}$} & $32(77)$ & $47(74)$ & \multirow{2}{*}{0.088} \\
\hline & $6-163$ & $14-168$ & \\
\hline \multirow{2}{*}{$\begin{array}{l}\text { Number of children, } \\
\text { Median (IQR), min-max }\end{array}$} & $2(1)$ & $2(1)$ & \multirow{2}{*}{0.380} \\
\hline & $1-3$ & $1-6$ & \\
\hline
\end{tabular}

Table 2. Comparisons of parents in terms of clinical characteristics according to the group and gender, $\mathrm{n}(\%)$

\begin{tabular}{|c|c|c|c|c|}
\hline & & $\begin{array}{c}\text { Normal } \\
\text { circumcision }\end{array}$ & Hypospadias & $\mathbf{p}_{\mathbf{c}}$ \\
\hline \multirow{4}{*}{$\begin{array}{l}\text { Any } \\
\text { psychiatric } \\
\text { diagnoses }\end{array}$} & Mother* & $0(0.0)$ & $1(4.2)$ & 0.312 \\
\hline & Father $^{\#}$ & $1(3.8)$ & $1(4.5)$ & 0.904 \\
\hline & $p_{r}$ & 0.332 & 0.950 & \\
\hline & Total & $1(2.0)$ & $2(4.3)$ & 0.606 \\
\hline \multirow{4}{*}{$\begin{array}{l}\text { Information } \\
\text { about } \\
\text { Hypospadias }\end{array}$} & Mother* & $13(54.2)$ & $18(75.0)$ & 0.131 \\
\hline & Father $^{\#}$ & $16(61.5)$ & $19(86.4)$ & 0.054 \\
\hline & $p_{r}$ & 0.598 & 0.464 & \\
\hline & Total & $29(58.0)$ & $37(80.4)$ & 0.018 \\
\hline \multirow{4}{*}{$\begin{array}{l}\text { Concerns } \\
\text { about child's } \\
\text { sexuality }\end{array}$} & Mother* & $12(50.0)$ & $6(25.0)$ & 0.074 \\
\hline & Father $^{\#}$ & $11(42.3)$ & $6(27.3)$ & 0.278 \\
\hline & $\mathbf{p}_{\mathbf{r}}$ & 0.586 & 0.861 & \\
\hline & Total & $23(46.0)$ & $12(26.1)$ & 0.043 \\
\hline \multirow{4}{*}{$\begin{array}{l}\text { Concerns } \\
\text { about child's } \\
\text { homosexuality }\end{array}$} & Mother* & $0(0.0)$ & $1(4.2)$ & 0.312 \\
\hline & Father $^{\#}$ & $0(0.0)$ & $1(4.5)$ & 0.458 \\
\hline & $p_{r}$ & --- & 0.950 & \\
\hline & Total & $0(0.0)$ & $2(4.3)$ & 0.227 \\
\hline
\end{tabular}

": there were 24 mothers both in normal circumcision and hypospadias groups, "\# there were 26 fathers in normal circumcision group and 22 in hypospadias group, $\mathrm{p}_{\mathrm{c}}$ : $\mathrm{p}$ value for comparison of column proportions in each gender and group, $\mathrm{p}_{\mathrm{r}}$ : $\mathrm{p}$ value for row comparisons (comparison of mother and father) in same group 
Table 3. Comparisons of parents in terms of state-trait anxiety scale according to the group and gender

\begin{tabular}{|c|c|c|c|c|}
\hline & & $\begin{array}{c}\text { Normal } \\
\text { circumcision }\end{array}$ & Hypospadias & $\mathbf{p}$ \\
\hline \multirow{4}{*}{ STAI-I } & Mother* & $36.04 \pm 8.09$ & $34.58 \pm 8.17$ & \multirow{2}{*}{0.980} \\
\hline & Father ${ }^{\#}$ & $35.69 \pm 9.07$ & $37.24 \pm 7.48$ & \\
\hline & $\mathbf{p}$ & \multicolumn{2}{|c|}{0.500} & \multirow{4}{*}{0.071} \\
\hline & Total & $35.86 \pm 8.53$ & $35.82 \pm 7.88$ & \\
\hline \multirow{4}{*}{ STAI-II } & Mother* & $42.63 \pm 6.23$ & $39.75 \pm 9.38$ & \\
\hline & Father ${ }^{\#}$ & $41.08 \pm 10.72$ & $37.62 \pm 5.71$ & \\
\hline & p & \multicolumn{2}{|c|}{0.291} & 0.867 \\
\hline & Total & $41.82 \pm 8.80$ & $38.76 \pm 7.87$ & \\
\hline \multirow{4}{*}{ STAI } & Mother* & $78.67 \pm 12.28$ & $74.33 \pm 14.89$ & \multirow{2}{*}{0.278} \\
\hline & Father $^{\#}$ & $76.77 \pm 16.53$ & $74.86 \pm 10.41$ & \\
\hline & $\mathbf{p}$ & \multicolumn{2}{|c|}{0.811} & 0.673 \\
\hline & Total & $77.68 \pm 14.53$ & $74.58 \pm 12.85$ & \\
\hline
\end{tabular}

STAI: State-Trait Anxiety Scale, ${ }^{*}$ : there were 24 mothers both in normal circumcision and hypospadias groups, \#: there were 26 fathers in normal circumcision group and 22 in hypospadias group
Table 4. Comparisons of parents of children with hypospadias in terms of state-trait anxiety scale according to the gender and having information about hypospadias

\begin{tabular}{|c|c|c|c|c|}
\hline & & Information (+) & Information (-) & $\mathbf{p}$ \\
\hline \multirow{4}{*}{ STAI-I } & Mother* & $34.56 \pm 8.48$ & $34.67 \pm 7.89$ & \multirow{2}{*}{0.201} \\
\hline & Father ${ }^{\#}$ & $36.67 \pm 7.87$ & $40.67 \pm 3.51$ & \\
\hline & $\mathbf{p}$ & \multicolumn{2}{|c|}{0.514} & 0.537 \\
\hline & Total & $35.61 \pm 8.13$ & $36.67 \pm 7.14$ & \\
\hline \multirow{4}{*}{ STAI-II } & Mother ${ }^{*}$ & $40.28 \pm 8.55$ & $38.17 \pm 12.34$ & \multirow{2}{*}{0.587} \\
\hline & Father $^{\#}$ & $37.67 \pm 5.98$ & $37.33 \pm 4.61$ & \\
\hline & $\mathbf{p}$ & \multicolumn{2}{|c|}{0.700} & 0.779 \\
\hline & Total & $38.97 \pm 7.39$ & $37.89 \pm 10.03$ & \\
\hline \multirow{4}{*}{ STAI } & Mother* & $74.83 \pm 13.81$ & $72.83 \pm 19.18$ & \multirow{2}{*}{0.655} \\
\hline & Father ${ }^{\#}$ & $74.33 \pm 10.86$ & $78.00 \pm 7.94$ & \\
\hline & $\mathbf{p}$ & \multicolumn{2}{|c|}{0.873} & 0.588 \\
\hline & Total & $74.58 \pm 12.25$ & $74.56 \pm 15.88$ & \\
\hline
\end{tabular}

STAI: State-Trait Anxiety Scale, *: there were 18 mothers having information about hypospadias and 6 not having, \#: there were 19 fathers in having information about hypospadias and 3 not having
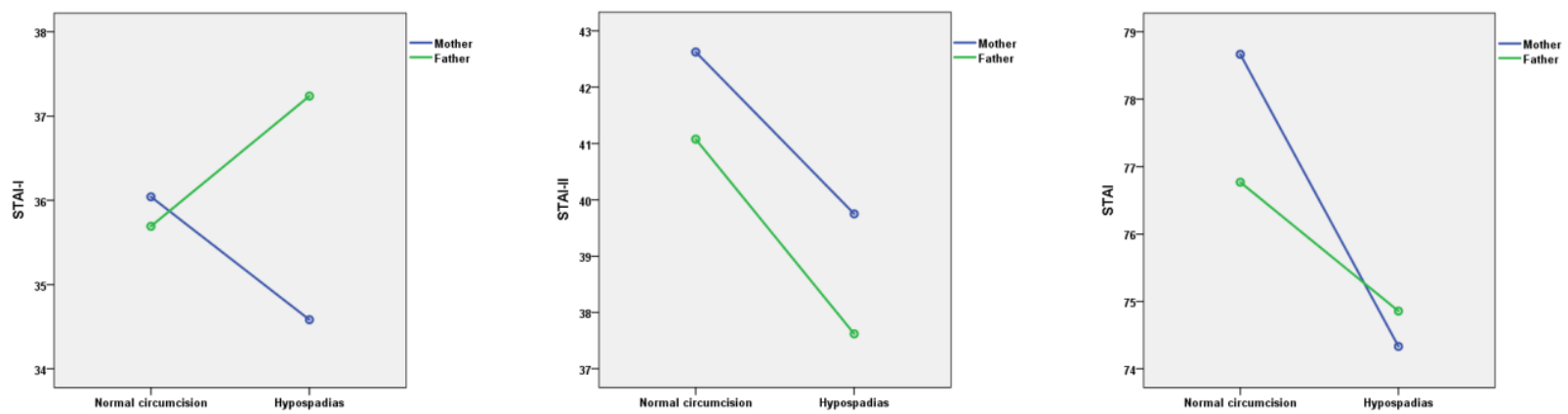

Figure 1. State-trait anxiety scale points according to the group and gender
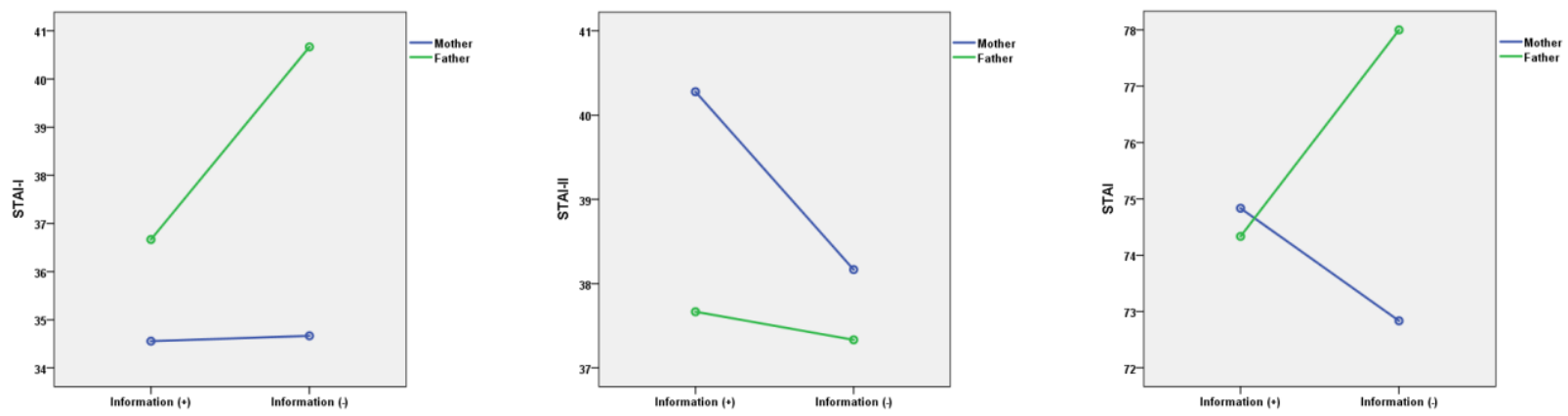

Figure 2. State-trait anxiety scale points according to the gender and information about hypospadias

\section{DISCUSSION}

Detection of hyperthymic temperament in fathers of circumcision group was the most remarkable result obtained from the parents of children with hypospadias and of children with normal circumcision. Hyperthymic temperament has characteristics such as optimism, extroversion, sociality and self-confidence (15). It may be thought that fathers in the circumcision group are more optimistic and social and thus may help to reduce the stress of their children compared to the hypospadias group. Conversely, it may be thought that fathers in the hypospadias group may not help enough to reduce the stress of their children. 
Y1ldirım et al. (16) have shown in a study conducted with ankylosing spondylitis (AS), a significant relationship between BAI and BDI scores and depressive, cyclothymic, irritable, and anxious temperaments. This result suggests that affective temperament except hyperthymic temperament could be a risk factor for depression and anxiety in AS patients. But in our study, fathers of normal circumcision children have higher trait anxiety scores accompanying hyperthymic temperament. In another study conducted by Fistıkçı et al. (17) hyperthymic temperament scores were higher in Panic Disorder patients. This result suggests that hyperthymic temperament could be a risk factor for trait anxiety in fathers of normal circumcision children.

There are very limited studies on hypospadias and its longterm outcomes. Most of these studies are on the anatomy and function of the penis, and sexual dysfunction. The general opinion obtained from all studies is that hypospadias surgery before the age of 5.5 makes a positive psychological contribution to the child (18). In another study conducted on Turkish children, it was found that the most important parameter of the emotional effect detected in children underwent hypospadias surgery was the age of surgery (19). Personality traits of the child, how the child is prepared for circumcision in pre-circumcision period, and physical problems experienced during and after operation may play a role in circumcision causing psychiatric disorders in some children. How families perceive circumcision and reflect it to their children can also be an important factor. When the groups in our study were evaluated, it was observed that the age of the children in the circumcision group and hypospadias group were similar and homogenous, and the mean age was 5 years in accordance with the literature. While it is stated that psychological trauma in children can be prevented with relatively early surgery, there are no studies on parents in the literature. However, it may be thought that parents of children undergoing hypospadias surgery at small ages may get really stressed. In other words, surgery performed at an early age may cause an increase in the psychological trauma of the parents. However, when the two groups were evaluated in our study, we found that the age distribution was homogenous and there was no statistically significant difference depending on the age in the evaluation of anxiety status.

Especially the temperament traits of mothers play an important role on child. The irritable temperament traits of mother are important in terms of both the quality of maternal support child perceived and angry and impulsive parent relationship (20). Irritable temperament traits are also characterized by impaired social function and interpersonal relationships. In our study, we found that the mothers of the hypospadias group showed no irritable temperament trait. From this point of view, we think that there was no statistically significant difference in temperament characteristics between mothers in both groups because they were informed about the hypospadias since birth and they were prepared for the operation process.

It is a known fact that social media is widely used today. In a study conducted on social media, after 736 cases were examined with hypospadias, it was detected that $7.1 \%$ $(n=52)$ of them was remained untreated. As a result of this study, it can be seen that patients or their parents are still hesitating for hypospadias surgery and do not have the necessary operation done. Although there are various risks such as sexual dysfunction, cosmetic problems in the penis and even infertility, surgical stress in patients or parents caused by the operation planned to be performed may be the reason why $7.1 \%$ of patients are not having operation (21). In our study, parents who abstained from the operation and therefore developed serious anxiety disorders did not bring their children and therefore were not included in the study. In fact, study with parents of children with hypospadias in the whole society, not only with parents of children underwent surgery, may have different results. The fact that our study was performed only with the parents of children with hypospadias who accepted the operation can be considered as one of the limitations of the study.

Depression and emotional status in children are directly influenced by behavior, attitude and socioeconomic status of parents (22). In our study, we did not find any socioeconomic difference between the parents of hypospadias and circumcision groups.

Hypospadias is a complex developmental defect and all patients are treated with different techniques and it requires special expertise and knowledge. In men who underwent hypospadias surgery, sexual dysfunctions that develop in further period usually develop on psychological basis (23-25). Due to insufficient information acquired on the internet and social media, anxiety level of parents usually increases. In our study, detection of hyperthymic temperament character in the circumcision group compared to the hypospadias group, especially in fathers, supports this situation.

As a result, parents' anxiety levels should be taken into consideration and everyone should act together in management process of hypospadias which have many effects in the future. We think that this study which was done with the family of children operated for hypospadias may guide to other studies.

\section{REFERENCES}

1. Snodgrass W, Macedo A, Hoebeke P, Mouriquand PD. Hypospadias dilemmas: a round table. J Pediatr Urol. 2011;7(2):145-57.

2. Manley CB. Elective genital surgery at one year of age: psychological and surgical considerations. Surg Clin North Am. 1982;62(6):941-53.

3. Schultz JR, Klykylo WM, Wacksman J. Timing of elective hypospadias repair in children. Pediatrics. 1983;71(3):342-51.

4. Sugar M. Consolidation of gender identity. In: Noshpitz JD, editor. Handbook of child and adolescent psychiatry. Volume 3. New York: John Wiley and Sons; 1997. p.155-66.

5. Sugar M. At-risk factors for the adolescent mother and her infant. J Youth Adolesc. 1976;5(3):251-70.

6. Blotcky MJ, Grossman I. Psychological implications of childhood genitourinary surgery. An empirical study. J Am Acad Child Psychiatry. 1978;17(3):48897.

7. Sandberg DE, Meyer-Bahlburg HF, Aranoff GS, Sconzo JM, Hensle TW. Boys with hypospadias: a survey of behavioral difficulties. J Pediatr Psychol. 
1989;14(4), 491-514.

8. Sandberg DE, Meyer-Bahlburg HF, Hensle TW, Levitt SB, Kogan SJ, Reda EF. Psychosocial adaptation of middle childhood boys with hypospadias after genital surgery. J Pediatr Psychol. 2001;26(8), 465-75.

9. Öner N, LeCompte A. State-trait anxiety inventory handbook. İstanbul: Boğaziçi University; 1985.

10. Gökçe T, Dündar C. The frequency of exposing to violence and its effects on state and trait anxiety levels among the doctors and nurses working in Samsun Psychiatry Hospital. İnönü Üniv Tip Fak Derg. 2008;15(1):25-8.

11. Vahip S, Kesebir S, Alkan M, Yazici O, Akiskal KK, Akiskal HS. Affective temperaments in clinically-well subjects in Turkey: initial psychometric data on the TEMPS-A. J Affect Disord. 2005;85(1-2):113-25.

12. Akiskal HS, Akiskal KK. TEMPS: Temperament Evaluation of Memphis, Pisa, Paris and San Diego. J Affect Disord. 2005;85(1-2):1-2.

13. Beck AT, Steer RA. Internal consistencies of the original and revised Beck Depression Inventory. J Clin Psychol. 1984;40(6):1365-7.

14. Hisli N. Beck Depresyon envanterinin üniversite öğrencileri için geçerliği, güvenirliği. Psikoloji Dergisi. 1989;7(23):3-13.

15. Akiskal HS, Mallya G. Criteria for the "soft" bipolar spectrum: treatment implications. Psychopharmacol Bull. 1987;23(1):68-73.

16. Yildirim T, Solmaz D, Emul M, Akgol G, Yalvac D, Ersoy Y. Affective temperament profile in ankylosing spondylitis patients using TEMPS-A. J Phys Ther Sci. 2017;29(3):394-400.

17. Fistikci N, Hacioğlu M, Erek Ş, Tabo A, Erten E, Güler AS, et al. Differences in affective temperaments in anxiety disorders: comparison of panic disorder and obsessive compulsive disorder. Noro Psikiyatr Ars. 2013;50(4):337-43.

18. Jones BC, O'Brien M, Chase J, Southwell BR, Hutson JM. Early hypospadias surgery may lead to a better long-term psychosexual outcome. J Urol. 2009;182(4 Suppl):1744-9.

19. Eray N, Dogangun B, Kayaalp L, Emir H, Soylet Y, Danismend N, et al. Emotional effects of hypospadias surgery on Turkish boys. J Pediatr Urol. 2005;1(2):7580.

20. Kesebir S, Vahip S, Akdeniz F, Yüncü Z. The relationship of affective temperament and clinical features in bipolar disorder. Turk Psikiyatri Derg. 2005;16(3):164-9.

21. Schlomer B, Breyer B, Copp H, Baskin L, Disandro M. Do adult men with untreated hypospadias have adverse outcomes? A pilot study using a social media advertised survey. J Pediatr Urol. 2014;10(4):672-9.

22. Beautrais AL, Joyce PR, Mulder RT. Risk factors for serious suicide attempts among youths aged 13 through 24 years. J Am Acad Child Adolesc Psychiatry. 1996;35(9):1174-82.

23. Mureau MA, Slijper FM, Nijman RJ, van der Meulen JC, Verhulst FC, Slob AK. Psychosexual adjustment of children and adolescents after different types of hypospadias surgery: a norm-related study. J Urol. 1995;154(5):1902-7.

24. Mureau MA, Slijper FM, van der Meulen JC, Verhulst FC, Slob AK. Psychosexual adjustment of men who underwent hypospadias repair: a norm-related study. J Urol. 1995;154(4):1351-5.

25. Mureau MA, Slijper FM, Slob AK, Verhulst FC. Psychosocial functioning of children, adolescents, and adults following hypospadias surgery: a comparative study. J Pediatr Psychol. 1997;22(3):371-87. 